\title{
Notes
}

\section{The Presumption of Life: A Starting Point for a Due Process Analysis of Capital Sentencing}

As early as 1354, English law recognized that the sovereign could not put an individual to death without providing that individual with due process of law. While the drafters of our Bill of Rights subsequently incorporated the principle of due process into American law, and our legal system still invokes it as a constitutional safeguard, American courts are currently sentencing capital defendants to death without according them this protection. The United States Supreme Court has attempted to provide some procedural safeguards to these defendants through the Eighth Amendment's ban on cruel and unusual punishments, and has invoked specific guarantees of due process in a few cases, but this effort is inadequate in practice and misguided in theory.

In 1976 , less than five years after invalidating all capital punishment statutes in the nation, ${ }^{2}$ the Supreme Court upheld the Georgia, Florida, and Texas statutes against Eighth Amendment challenges. ${ }^{3}$ Since then, the Court has relied extensively upon the procedures contained in those three state statutes to determine the constitutionally required elements of capital sentencing proceedings. ${ }^{4}$ A significant body of Eighth Amendment

1. The law provided that: "[N]o Man of what Estate or Condition that he be, shall be put out of Land or Tenement, nor taken, nor imprisoned, nor disinherited, nor put to death, without being brought in answer by due process of the law." 28 Edw. 3, ch. 3 (1354), quoted in F. THOMPSON, Magna Carta: Its Role in the Making of the English Constitution 1300-1629, at 92 \& n.72 (1948).

2. Furman v. Georgia, 408 U.S. 238 (1972) (per curiam).

3. Gregg v. Georgia, 428 U.S. 153 (1976); Proffitt v. Florida, 428 U.S. 242 (1976); Jurek v. Texas, 428 U.S. 262 (1976).

4. The three state statutory schemes have taken on more than precedential weight. The Court's recent refusal to hold that the Eighth Amendment requires proportionality review in capital sentencing systems was based in part on the lack of such a procedure in the Texas system upheld in Jurek. Pulley v. Harris, 104 S. Ct. 871 (1984). The Court reasoned that it could not require that the California system include the procedure without overruling Jurek. Id. at 879 . The Court so held even though the Georgia statute and the Florida system, upheld under the Eighth Amendment at the same time as Jurek, provided for such a review. Id. at 876 . The majority reasoned that the Georgia and 
analysis has developed around the 1976 cases, ${ }^{8}$ but the Court has not recognized any core values from which minimal standards of procedural protection can evolve. ${ }^{8}$

The Court has not adequately analyzed the impact of the due process clause of the Fourteenth Amendment on capital sentencing systems. Because of its text and history, the due process clause provides better authority for establishing the minimal procedures that should underlie all capital sentencing proceedings than does the Eighth Amendment. By refusing to rely upon the due process clause, the Court has permitted states to develop capital sentencing schemes that disregard the fundamental values of our system of criminal procedure.

This Note asserts that the starting point for a due process analysis of a capital sentencing system should be a presumption of life, ${ }^{7}$ analogous to

Florida opinions "were focused not on proportionality review as such, but only on the provision of some sort of prompt and automatic appellate review." Id. at 879.

In Zant v. Stephens, 103 S. Ct. 2733 (1983), the Court relied upon Gregg in upholding a Georgia death sentence imposed by a jury that had been instructed to consider an aggravating circumstance subsequently found to be unconstitutionally vague. In rejecting Stephens' argument that the jury had been given too much discretion, the Court reasoned that the "argument could not be accepted without overruling our specific holding in Gregg." Id. at 2742. Although Gregg did not address the issue of unlawful jury instructions, the Court asserted that Gregg and Jurek had made it "clear that specific standards for balancing aggravating against mitigating circumstances are not constitutionally required." Id. at 2742 n.13. Ironically, the Court itself had found it necessary in Stephens to certify a question to the Georgia Supreme Court to clarify the state's capital sentencing law. See Zant v. Stephens, 456 U.S. 410, 416-17 (1982) (per curiam).

The Court also relied on Jurek to approve the use of testimony on the future dangerousness of a defendant by psychiatrists who had never examined the defendant. "At bottom, to agree with petitioner's basic position would seriously undermine and in effect overrule Jurek $v$. Texas." Barefoot v. Estelle, 103 S. Ct. 3383, 3400 (1983). Yet the Jurek Court had not examined the issue of psychiatric testimony. The Supreme Court's review of the evidence presented at Jurek's trial did not mention any such evidence. Jurek v. Texas, 428 U.S. at 266-67 (opinion of Stewart, Powell, \& Stevens, JJ.). The Court's analysis focused on laypersons' predictions of future dangerousness. Id. at 275-76.

5. The major procedural requirements of the Eighth Amendment in capital sentencing are "an individualized determination on the basis of the character of the individual and the circumstances of the crime," Zant v. Stephens, 103 S. Ct. 2733, 2744 (1983) (emphasis in original), and some type of automatic appellate review, Pulley v. Harris, 104 S. Ct. 871, 879 (1984).

6. In the same case where the Court relied on Jurek to uphold the California capital sentencing system, it restated the Gregg Court's position that "[w]e do not intend to suggest that only the abovedescribed procedures would be permissible under Furman or that any sentencing system constructed along these general lines would inevitably satisfy the concerns of Furnan, for each distinct system must be examined on an individual basis." "Pulley v. Harris, 104 S. Ct. 871, 876 (1984) (quoting Gregg, 428 U.S. at 195 (footnote omitted)); see also Spaziano v. Florida, 104 S. Ct. 3154, 3165 (1984) (Court "unwilling to say that there is any one right way for a State to set up its capital-sentencing scheme"). Although states may enact various statutory procedures that should be examined individually for Eighth Amendment violations, this Note argues that courts must also evaluate these procedures against a basic constitutional due process standard, just as they evaluate traditional criminal trial procedures. See infra note 13.

7. The use of the term "presumption of life" in this Note should be distinguished from its use by courts in other contexts. Historically, the term has been used by federal and state courts in disappearance cases "where the issue is upon the life or death of a person, once shown to have been living, the burden of proof lies upon the party, who asserts the death. But after the lapse of seven years, without intelligence concerning the person, the presumption of life ceases, and the burden of proof is devolved on the other party." 1 S. Greenleaf, A Treatise on the Law of Evidence $\$ 41$, at 47 (Boston 
the presumption of innocence that orders our criminal trials. The presumption of life guarantees a convicted defendant the right to live incarcerated for life unless the prosecution demonstrates beyond a reasonable doubt that death is the only appropriate penalty for the defendant. The Note establishes that a constitutional mandate ${ }^{8}$ of a presumption of life arises from the same source and rationale that support the constitutionally required presumption of innocence. The Note then analyzes some of the procedural consequences of a presumption of life, focusing especially on the function of the bifurcated trial proceeding. Finally, the Note identifies the method of burden allocation and some of the mechanisms for judicial review inherent in a sentencing system built on this foundation.

\section{The Supreme Gourt's Selective Enforcement of Procedural Protections in Gapital Sentencing}

Despite the Supreme Court's repeated reliance on its 1976 opinions, the Court nevertheless has modified its Eighth Amendment assessments of

1842) (emphasis in original) (footnotes omitted); accord Bowman v. Redding \& Co., 449 F.2d 956, 961 (D.C. Cir. 1971) (where time of death uncertain, there is presumption of continuance of life). The Wisconsin courts have approved a jury instruction on the presumption of life during abortion prosecutions and have asserted that there is a "presumption that life from conception continue[s]." State v. Gresens, 40 Wis. 2d 179, 184-85, 161 N.W.2d 245, 248 (1968) (relying on 1 F. WHARTON, Wharton's Criminal. Evidence $§ 115$ (12th ed. 1955)).

Only one court appears to have mentioned a presumption of life in a capital punishment context. While holding that the presumption of innocence had no direct application to the capital sentencing determination, the Pennsylvania Supreme Court recognized the heavier burdens placed on the prosecution in a capital sentencing proceeding and "acknowledged that in some sense there is a "presumption of life" " implicit in the proceeding. Commonwealth v. Travaglia, $502 \mathrm{~Pa}$. 474, $467 \mathrm{~A} .2 \mathrm{~d} 288,300$ (1983), cert. denied, 104 S. Ct. 3547 (1984). Without further analysis the court held that a comment during the sentencing phase by the prosecution on the lack of remorse of the defendant was properly allowed by the trial judge. 467 A.2d at 301 .

8. The notion that the criminal law should favor the preservation of the capital defendant's life rather than the execution of the individual is not, of course, a new concept. The common law has long recognized that in capital cases "there is, in favorem vitae," certain extra safeguards allowed to the accused. See 4 W. Blackstone, Commentaries *353, quoled in Swain v. Alabama, 380 U.S. 202, 212 n.9 (1965) (explaining origin of peremptory challenge); see also Green v. United States, 355 U.S. 184,215 (1957) (Frankfurter, J., dissenting) (arguing that "to fashion a policy in favorem vitae" as majority opinion had done in foreclosing retrial of capital charges was barred by precedent); Rankin v. Tennessee, 78 U.S. (11 Wall.) 380, 381-82 (1871) ("It is a rule in criminal law in favorem vitae, in capital cases, that when a special plea in bar is found against the prisoner . . . [he] may plead over to the felony the general issue, not guilty."); Sanford v. Robbins, 115 F.2d 435, 439 (5th Cir. 1940), cert. denied, 312 U.S. 697 (1941) (presuming in favorem vitae that individual condemned to death consented to new trial, since he had never expressed desire to be executed). The South Carolina Supreme Court has employed the doctrine most often and most consistently in capital cases as a standard of appellate review. E.g., State v. Patterson, 278 S.C. 319, 320, 295 S.E.2d 264, 264-65 (1982) ("On appeal from a murder conviction in which the death penalty is imposed, this court reviews the entire record for prejudicial error in favorem vitae, regardless of whether the error was properly preserved for review."); see McDonald, Capital Punishment in South Carolina: The End of an Era, 24 S.C.L. REv. 762, 774-80 (1972) (tracing history of use of principle by South Carolina Supreme Court and its impact on reversals of capital convictions).

9. See supra note 4 . 
those state statutes. ${ }^{10}$ There purportedly has emerged a "procedural due process strain in eighth amendment analysis."11 The Supreme Court has acknowledged that in capital cases "the sentencing process, as well as the trial itself, must satisfy the requirements of the Due Process Clause,"12 but has not attempted to articulate the core values ${ }^{13}$ of capital sentencing due process.

\section{A. Fundamental Procedural Fairness}

The few capital cases in which the Supreme Court has relied on the due process clause give little guidance on the extent to which due process applies to capital sentencing. Most of the Court's opinions concerning capital sentencing that mention the Fourteenth Amendment have not referred specifically to the due process clause, citing the Fourteenth Amendment only as the provision through which the Eighth Amendment applies to the states. ${ }^{14}$ In three cases, however, the Court has explicitly invoked the due process clause to invalidate a practice in a capital sentencing proceeding. In Gardner $v$. Florida ${ }^{15}$ the Court vacated the death sentence, imposed by a judge over a jury recommendation of life imprisonment, because the judge had relied in part on a presentence investigation report that was not disclosed to the defendant. The Court held that the nondisclosure of the report violated the requirements of due process since the state did not have sufficient justification for withholding the report. ${ }^{18}$ The Court supported the due process reasoning by observing that defendants

10. For example, although the Georgia statute was upheld on its face in Gregg, two specific features of the statute have since been declared unconstitutional by the Supreme Court. See Godfrey v. Georgia, 446 U.S. 420,432 (1980) (plurality opinion) (setting aside death sentence based on aggravating factor interpreted so broadly by Georgia courts that it was unconstitutional although challenge to same factor had been specifically rejected by Gregg Court, 428 U.S. at 201); Coker v. Georgia, 433 U.S. 584, 592 (1977) (plurality opinion) (vacating death sentence imposed under Georgia statute on defendant convicted of rape of adult woman because death was disproportionate punishment for offense and therefore violated Eighth Amendment); see also Arnold v. State, $236 \mathrm{Ga}$. 534, 539-42, 224 S.E.2d 386, 391 (1976) (Georgia Supreme Court declaring unconstitutionally vague the aggravating circumstance in Georgia statute of "substantial history of serious assaultive criminal convictions").

11. Radin, Cruel Punishment and Respect for Persons: Super Due Process for Death, 53 S. CAL. L. REv. 1143, 1144 (1980) (analyzing judicial review of process as cruel).

12. Gardner v. Florida, 430 U.S. 349,358 (1977) (plurality opinion).

13. The Court has recognized core due process values of criminal trials. See, e.g., Estelle v. Williams, 425 U.S. 501, 503 (1976) (presumption of innocence underlies our criminal justice system); In re Winship, 397 U.S. 358, 364 (1970) (because citizens must have confidence in our criminal justice system, prosecution must establish proof beyond a reasonable doubt to convict an individual).

14. See, e.g., Godfrey v. Georgia, 446 U.S. 420, 423 (1980) (plurality opinion) (declaring provision of Georgia capital punishment statute violated Eighth and Fourteenth Amendments); Lockett v. Ohio, 438 U.S. 586, 599, 604-05 (1978) (opinion of Burger, C.J.) (holding that Ohio death penalty statute that precluded consideration of relevant mitigating factors violated Eighth and Fourteenth Amendments).

15. 430 U.S. 349 (1977) (plurality opinion).

16. Id. at 361-62. 
have a right to the effective assistance of counsel at sentencing ${ }^{17}$ and that defendants have a legitimate interest in the character of the sentencing procedure. ${ }^{18}$ Although the Court expressly stated that the mere application of due process does not "implicate the entire panoply of criminal trial procedural rights," and that "[o]nce it is determined that due process applies, the question remains what process is due," did not address the critical question of the exact extent of due process protections. Subsequent actions by the Supreme Court show that Gardner's due process rationale has had little enduring influence. ${ }^{20}$

The following year, the Court issued a per curiam opinion in Presnell v. Georgia, ${ }^{21}$ declaring that a death sentence that was based on an underlying rape charge of which the defendant was not properly convicted violated the fundamental principles of procedural fairness, and therefore was unconstitutional under the due process clause. ${ }^{22}$ The next year, in Green v. Georgia, ${ }^{23}$ the Court held, in another per curiam opinion, that the exclusion of hearsay evidence offered in mitigation denied the defendant due process, but noted that this due process violation arose under "unique circumstances." 24

The absence of a majority opinion in these three cases indicates that the Court has failed not only to articulate due process guidelines, but has failed even to agree that due process applies in capital sentencing. ${ }^{26}$ Individual Justices ${ }^{28}$ and commentators, however, continue to assert that a de-

17. Id. at 358 (citing Mempa v. Rhay, 389 U.S. 128 (1967), and Specht v. Patterson, 386 U.S. 605 (1967)).

18. Id. (citing Witherspoon v. Illinois, 391 U.S. 510, 521-23 (1968)).

19. Id. at 358 n.9 (quoting in part, Morrissey v. Brewer, 408 U.S. 471, 481 (1972)).

20. Compare, for example, the Court's subsequent refusal to hear capital defendants' claims that ex parte nonrecord sentencing data relied upon by the Florida Supreme Court must be disclosed. Brown v. Wainwright, 454 U.S. 1000, 1001 (1981) (Marshall, J., joined by Brennan, J., dissenting from denial of certiorari); see also Alford v. Florida, 436 U.S. 935, 939 (1978) (Marshall, J., joined by Brennan, J., dissenting from denial of certiorari) (nonrecord information about defendant communicated ex parte by probation supervisor to trial judge but not revealed to defendant).

21. 439 U.S. 14 (1978) (per curiam).

22. Id. at 15-17.

23. 442 U.S. 95 (1979) (per curiam).

24. Id. at 97 (hearsay evidence concerned co-defendant's confession to the murder with which Green was charged).

25. Justice White expressly rejected the Court's application of the due process clause to sentencing in Gardner and concurred on Eighth Amendment grounds. Gardner v. Florida, 430 U.S. 349, 364 (1977) (White, J., concurring in judgment).

26. See Barefoot v. Estelle, 103 S. Ct. 3383, 3410 n.6 (1983) (Blackmun, J., dissenting). Justice Blackmun, in a dissenting opinion joined by Justices Brennan and Marshall, found that the "misleading nature of any psychiatric prediction of future violence violates due process when introduced in a capital sentencing hearing ...." The majority opinion rejected the due process challenge without analysis. Id. at 3400 . In an even more recent case, Justice Stevens, in an opinion joined by Justices Brennan and Marshall, quoted the provisions of the Fourteenth Amendment and discussed the applicability of due process of law to the deprivation of life as requiring unique safequards. Spaziano v. Florida, 104 S. Ct. 3154, 3167 (1984) (Stevens, J., concurring in part and dissenting in part). Justice Stevens ultimately reasoned that the procedural right to a trial by jury before deprivation of liberty 
fendant does have a right to due process of law in a capital sentencing proceeding and that state sentencing procedures frequently violate this right. ${ }^{27}$

\section{B. Specific Procedural Protections}

While the Supreme Court has been unwilling to apply due process with full force to capital sentencing, it has applied certain specific procedural protections. When faced with arguments that courts should require particular procedural safeguards in capital sentencing proceedings, the Court inevitably ${ }^{28}$ asserts that a capital sentencing proceeding resembles a trial in some respects, but not in all, and therefore some but not all of the procedural protections apply. ${ }^{29}$ Through this method of analysis, the Court has determined that the double jeopardy clause of the Fifth Amendment applies to the penalty phases of capital trials in Arizona ${ }^{30}$ and Missouri. $^{31}$ It has also held that the provisions against self-incrimination of the Fifth Amendment and the Sixth Amendment right to the assistance of counsel apply in capital sentencing proceedings in Texas. ${ }^{32}$

Recently, however, a majority of the Supreme Court joined an opinion characterizing the nature of a life/death decision at the penalty phase of a capital trial as fundamentally different from a guilt/innocence decision, ${ }^{33}$ because there was no central issue in the penalty phase ${ }^{34}$ on which the jury's attention was focused. This reasoning, however, cannot properly extend to all state statutory schemes. The supporting analysis referred to California's procedures, which do not place a burden on the prosecution

should be applied in capital sentencing proceedings before deprivation of life. $I d$. at 3175 . The majority of the Court apparently rejected the due process challenge, although the reasoning in its opinion addressed only the Sixth Amendment challenge. Id. at 3161-65.

27. See generally Weissman, Sentencing Due Process: Evolving Constitutional Principles, 18 WAKE Forest L. REv. 523, 530 (1982) (death penalty is sui generis and "[s]trict judicial scrutiny coupled with enhanced due process standards is therefore mandated to insure constitutional protection"); Note, The Death Penalty Cases: Shaping Substantive Criminal Law, 58 IND. L.J. 187, 204-06 (1982) (concept of procedural due process requires that defendant have right to jury at capital sentencing proceeding).

28. See, e.g., Spaziano v. Florida, 104 S. Ct. 3154, 3161-62 (1984) (although "[p]etitioner does not urge that capital sentencing is so much like a trial on guilt or innocence that it is controlled by" Supreme Court precedent guaranteeing right to jury trial, Court discusses argument for analogy anyway). But see Weisberg, Deregulating Death, 1983 SuP. Cr. Rev. 305, 347-58 (analyzing perceived breakdown in use of "trial metaphor" in capital sentencing cases reflected in Supreme Court opinions of 1982 Term).

29. Spaziano v. Florida, 104 S. Ct. 3154, 3162-65 (1984).

30. Arizona v. Rumsey, 104 S. Ct. 2305, 2310 (1984).

31. Bullington v. Missouri, 451 U.S. 430, 446 (1981).

32. Estelle v. Smith, 451 U.S. $454,462-63,471$ (1981).

33. California v. Ramos, 103 S. Ct. 3446, 3456 (1983).

34. But compare id. with Arizona v. Rumsey, 104 S. Ct. 2305, 2310 (1984). In the latter opinion, Justice O'Connor, who also wrote the Ramos opinion, reasoned that the defendant's initial life sentence "was undoubtedly an acquittal on the merits of the central issue in the proceeding-whether death was the appropriate punishment ...." (emphasis added). 
to persuade the sentencing authority of the appropriateness of sentencing the defendant to death, ${ }^{35}$ as some states do, ${ }^{36}$ and as all state statutes should. ${ }^{37}$ The Court has yet to analyze the nature of the capital sentencing decision free from the constraints of a particular state's statutory framework. This Note argues that such an analysis supports the adoption of procedural devices that place the burden of persuasion on the prosecution in capital sentencing.

\section{A Constitutional Point of Departure: The Presumption of Life}

The due process clauses oblige the judiciary to apply specific federal constitutional guarantees in criminal proceedings. The Supreme Court must develop a method of analyzing capital sentencing proceedings to assess whether they comport with a constitutional standard. The Court should follow its experience in developing the rest of its criminal procedure jurisprudence and focus first on the core due process values of capital sentencing, and only then determine the procedural implications of those values.

\section{A. The Constitutional Necessity of the Presumption of Innocence}

The Burger Court has held that the presumption of innocence is "a basic component of a fair trial"38 and that impairment of the presumption violates the Fourteenth Amendment. ${ }^{39}$ This holding reaffirmed an earlier Court's observation that the presumption is "the undoubted law, axiomatic and elementary, and its enforcement lies at the foundation of the administration of our criminal law."40

35. Cal. Penal. Code $\S 190.3$ (West Supp. 1984) ("trier of fact . . . shall impose a sentence of death if . . . aggravating circumstances outweigh the mitigating circumstances"); see Note, Capital Punishment and the Burden of Proof: The Sentencing Decision, 17 Cal. W.L. Rev. 316, 316-17 (1981).

36. See infra notes 105 and 106.

37. See infra note 104.

38. Estelle v. Williams, 425 U.S. 501, 503 (1976).

39. Id. at 503-06 (state cannot compel defendant to appear at trial in prison clothes because of possible impairment of presumption of innocence).

The Court has held that a jury instruction containing the precise expression "presumption of innocence" is a constitutional requirement in criminal trials unless, in light of the totality of the circumstances, the overall fairness of the trial ensures that the accused is not being deprived of due process of law. Kentucky v. Whorton, 441 U.S. 786, 789 (1979) (per curiam). Some Justices have asserted that "an instruction on the presumption of innocence is constitutionally required in every case where a timely request has been made." Id. at 791 (Stewart, J., joined by Brennan \& Marshall, JJ., dissenting). A trial court's failure to instruct the jury on the presumption of innocence can result in reversal of a conviction. See Taylor v. Kentucky, 436 U.S. 478, 490 (1978).

40. Coffin v. United States, 156 U.S. 432,453 (1895). For the classic treatment of the history of the presumption of innocence, see J. Thayer, A Preliminary Treatise on Evidence at The Common LAw 551-76 (1898). See generally Fox, The "Presumplion of Innocence" as Constitutional 
Continental ${ }^{41}$ and Socialist ${ }^{42}$ legal systems, as well as international resolutions, ${ }^{43}$ also include the presumption of innocence as a fundamental element of criminal procedure.

The presumption of innocence in American criminal procedure derives from our common-law heritage, the text of the Fifth and Fourteenth Amendments, and considerations of policy. American courts have traced the existence of the presumption of innocence as far back as Deuteronomy and Roman law. ${ }^{44}$ In the mid-seventeenth century, the legislature of colonial Massachusetts employed the presumption as a burden-allocation device in criminal trials. ${ }^{45}$ The presumption has always been closely associated with the requirement that the prosecution prove its case beyond a reasonable doubt, ${ }^{48}$ but is also considered to be an independent element of due process in criminal trials. ${ }^{47}$

The text of the Fifth Amendment ${ }^{48}$ protects an individual from criminal sanctions unless the government is able to obtain an indictment, prevail before the factfinder at the original trial, convict the individual without his or her own testimony, and accord the person due process of law. The requirement that the state accord individuals due process of law before depriving them of life, liberty, or property was subsequently included in the Fourteenth Amendment's directive to the states. ${ }^{49}$ When the Fifth Amendment was ratified in 1791, the presumption of innocence was already part of our common law. ${ }^{50}$ When the Fourteenth Amendment was

Doctrine, 28 CATH. U.L. Rev. 253 (1979) (discussing constitutional status of presumption and criticizing Court's holding in Taylor $v$. Kentucky for failure to provide precise language of jury instruction and failure to assess actual impact of instructions).

41. Both the French and the German systems of criminal law recognize the presumption of innocence. See Fletcher, Two Kinds of Legal Rules: A Comparative Study of Burden-of-Persuasion Practices in Criminal Cases, 77 Yale L.J. 880, 880-81 \& nn. 3-5 (1968).

42. The presumption of innocence figures prominently in the legal doctrine of the U.S.S.R. See

Fletcher, The Presumption of Innocence in the Soviet Union, 15 UCLA L. REv. 1203, 1205 (1968).

43. See Fletcher, supra note 41 , at 880 n.1.

44. See Coffin v. United States, 156 U.S. 432, 454-55 (1895).

45. See J. Thayer, supra note 40, at 552-54 (according to Records OF Massachusetts, presumption in favor of accused, operating in both civil and criminal trials, required plaintiff to prove case by sufficient evidence).

46. See Taylor v. Kentucky, 436 U.S. 478, 483 n.12 (1978) (tracing history of relationship between presumption of innocence and reasonable-doubt standard).

47. Id. at 490.

48.

No person shall be held to answer for a capital, or otherwise infamous crime, unless on a presentment or indictment of a Grand Jury, except in cases arising in the land or naval forces, ... nor . . . be subject for the same offence to be twice put in jeopardy of life or limb; nor ... be compelled in any criminal case to be a witness against himself, nor be deprived of life, liberty, or property, without due process of law ....

U.S. Const. amend V.

49. "No State shall . . . deprive any person of life, liberty, or property, without due process of law ...."U.S. ConsT. amend. XIV, § 1.

50. "[T]here can be no doubt that, if the principle [of the presumption of innocence] had not found formal expression in the common law writers at an earlier date [than 1802], yet the practice 
ratified in 1868 , the presumption was firmly established as a principle of due process. $^{51}$

Modern courts accept the presumption of innocence as a core component of criminal due process ${ }^{82}$ because it invokes at least three features of procedural fairness. First, the presumption ensures that the state's arrest, indictment, and arraignment of the accused are not considered evidence of guilt, ${ }^{53}$ and that the accused is judged only upon evidence and arguments presented at trial. ${ }^{54}$ This "spurging' effect"s5 of the presumption allows the defendant to start with a clean slate at trial, and is one of several procedures that help strip the state of its cloak of authority. ${ }^{58}$ Second, the presumption assigns to the prosecution the burden of producing evidence of the elements of the crime. ${ }^{57}$ Finally, the presumption places on the prosecution the burden of persuading the jury ${ }^{88}$ that a verdict of guilty is legally justified. ${ }^{50}$ The presumption that the prosecution must overcome is one of legal innocence, rather than factual innocence. ${ }^{60}$ The accused remains free from any criminal sanction until the jury is convinced that the individual is not only factually guilty, but also morally culpable. ${ }^{61}$ Soci-

which flowed from it has existed in the common law from the earliest time." Coffin v. United States, 156 U.S. 432, 455 (1895).

51. See 1 S. GREENLEAF, supra note $7, \S 34$, at 39 (published in 1842) ("the law presumes every man innocent") (emphasis in original); see also Coffin v. United States, 156 U.S. 432, 454-56 (1895) (tracing historical development of presumption of innocence).

52. Taylor v. Kentucky, 436 U.S. 478, 490 (1978); Estelle v. Williams, 425 U.S. 501, 503-04 (1976).

53. United States v. Thaxton, 483 F.2d 1071, 1073 (5th Cir. 1973) (discussing functions of presumption of innocence in criminal procedure).

54. Taylor v. Kentucky, 436 U.S. 478, 485 (1978).

55. Id. at 486.

56. See A. Goldstein, The State and the Accused: Balance of Advantage in Criminal Procedure, 69 Y YLE L.J. 1149, 1153 (1960) (discussing development of procedural safeguards to offset state's advantages in resources and authority in criminal proceedings).

57. Taylor v. Kentucky, 436 U.S. 478,484 n.12 (1978).

58. If the defendant has waived the right to a jury, the prosecution must, of course, persuade the trial judge of the appropriateness of convicting the defendant.

59. Taylor v. Kentucky, 436 U.S. $478,484 \mathrm{n} .12$ (1978). Traditionally in criminal cases there are two aspects of the burden of proof - the burden of production of evidence and the burden of persuasion. The burden of production is the burden of going forward with the evidence and presenting evidence that the crime occurred and that the defendant committed it. If the prosecution does not meet this burden, the defendant can move for a directed verdict of acquittal. W. LAFAvE \& A. Scotr, HANDBOOK ON CRIMINAL LAW \& 8, at 44 (1972). The burden of persuasion is the burden of convincing the jury beyond a reasonable doubt that all the elements of the crime are present including that the defendant is legally accountable. Both burdens must be met to obtain a conviction. Id.

60. See J. THAYER, supra note 40, at 552 (presumption in favor of defendant "is not founded on any notion that defendants generally are free from blame"). Modern commentators also suggest that persons charged with crimes are more often convicted than acquitted. W. LAFAVE \& A. ScorT, supra note $59, \S 8$, at 53 .

61. To characterize the determination of criminal guilt as a purely factual finding ignores an essential ingredient of that decisionmaking process. Criminal trial jurors not only must decide whether they are convinced beyond a reasonable doubt that in fact the defendant did commit the alleged act, but also must consider nonfactual elements, such as recklessness, or justifications and excuses that involve normative judgments. The ultimate conviction must be based on a finding of moral culpability 
ety's belief in the integrity of citizens must be upheld by presuming that an individual is legally innocent until the prosecution persuades the decisionmaker that the defendant's "violation of a proscription of the criminal law renders him [or her] properly subject to moral censure."

\section{B. The Presumption of Life as an Indispensable Feature of Capital Sentencing}

The same dictates of text and policy that ensure that a criminal defendant may be deprived of his or her liberty only after the prosecution has overcome the presumption of innocence at trial apply with equal, if not greater, force to require that the prosecution overcome the presumption of life in a capital sentencing proceeding before a defendant can be put to death.

\section{From an Eighth Amendment Analysis to a Fourteenth Amendment Jurisprudence}

If a lawyer unfamiliar with the history of capital punishment in this country were handed a copy of the Constitution and asked to determine what protections a capital defendant could claim, he or she would likely focus on the provisions in the Fifth and Fourteenth Amendments, the only references ${ }^{63}$ to the taking of a person's life in the Constitution. ${ }^{64}$ The inclusion of "life" as well as "liberty" and "property" in the due process clauses of the Fifth and Fourteenth Amendments suggests that the drafters viewed the state's depriving an individual of life as distinct from deprivations of liberty and property. ${ }^{65}$ The Court has considered the deprivation

and not simply on the occurrence of an act. Otherwise, the stigma of the criminal sanction that distinguishes it from civil liability would not be warranted. See Arenella, Rethinking the Functions of Criminal Procedure: The Warren and Burger Couris' Competing Ideologies, 72 GEo. L.J. 185, 197-98 (1983); $c f$. Fletcher, supra note 41, at 888-92 (asserting that state can only justify punishing persons who are morally culpable and that appearance of strict liability standards in criminal law is aberrational).

62. Fletcher, supra note 41 , at 889 (footnote omitted).

63. See supra notes 48 and 49 (quoting text of relevant provisions).

64. Some have relied on the references to capital punishment in the Constitution to defend the use of the death penalty in modern American society. One of the most notable proponents of this position was Justice Black. See McGautha v. California, 402 U.S. 183, 225-26 (1971) (opinion of Black, J.). This Note does not adopt this position nor does it address the issue of the constitutionality of the death penalty. This Note limits its analysis to the threshold procedural protections constitutionally required in capital sentencing schemes, and assumes, arguendo, that according to the rationales in Gregg, capital punishment is not per se unconstitutional. For a persuasive argument that the inherent inaccuracies of the criminal justice system make it inappropriate ever to impose the irrevocable sentence of death, see C. Black, Capital Punishment: The Inevitability of Caprice and Mistake (2d ed. augmented 1981); see also Bruck, Decisions of Death: The Lottery of Capital Punishment is Rigged by Race, The New Republic, Dec. 12, 1983, at 18 (describing recent studies indicating racially discriminatory impact of capital sentencing systems).

65. Justice Brennan has noted, in the course of discussing the constitutional references to capital punishment, that we can infer that the framers of the procedural protection clause of the Fifth 
of life as an interest independent of liberty or property in several contexts. ${ }^{86}$ Clearly, the execution of an individual falls within the concept of a deprivation of life by the state. ${ }^{67}$

The failure of capital punishment jurisprudence to focus on the due process clauses, and to rely instead upon the Eighth Amendment, is largely a result of the sequence in which particular cases reached the Supreme Court. The landmark cases of McGautha v. California ${ }^{68}$ Furman v. Georgia ${ }^{69}$ and Gregg $v$. Georgia ${ }^{70}$ were decided within a span of five years. Only thirteen months after a five-Justice majority in $M c G a u t h a^{\mathbf{7 1}}$ rejected the argument that capital punishment procedures in California and Ohio violated the due process clause, the Gourt issued a per curiam judgment in Furman declaring that the death penalty procedures in Texas and Georgia were unconstitutional. ${ }^{72}$ Each of the nine Justices

Amendment recognized that it applied to persons charged with crimes punishable by death. Furman v. Georgia, 408 U.S. 238, 283 (1972) (Brennan, J., concurring).

66. An early Fourteenth Amendment case stated that "the fundamental rights to life, liberty, and the pursuit of happiness, considered as individual possessions, are secured by those maxims of constitutional law ...." Yick Wo v. Hopkins, 118 U.S. 356, 370 (1886). The Court also asserted that "the very idea that one man may be compelled to hold his life, or the means of living, or any material right essential to the enjoyment of life, at the mere will of another, seems to be intolerable in any country where freedom prevails...."Id. Recently, life has been regarded under the equal protection clause as an independent fundamental value. Roe v. Wade, 410 U.S. 113 (1973) (right of woman to have abortion balanced against right of unborn fetus). Recognizing the strong value placed on life, the Court determined that the viability of the fetus, that is the point at which the fetus is capable of living outside the mother's womb, was the critical issue distinguishing when the state can proscribe an abortion from when it cannot. Id. at 163; see also Spaziano v. Florida, 104 S. Ct. 3154, 3167 (1984) (Stevens, J., joined by Brennan \& Marshall, JJ., concurring in part and dissenting in part) ("The concept of due process permits no.. . deprivation-whether of life, liberty or property-to occur if it is grossly excessive . . . ."); Garner v. Memphis Police Dep't, 710 F.2d 240, 246-47 (6th Cir. 1983), probable jurisdiction noted in part and cert. granted in part, 104 S. Ct. 1589 (1984) (Nos. 83-1035 and 83-1070, cases consolidated) (striking down Tennessee's "fleeing felon" statute that permitted police officers to shoot escaping suspects as violative of Fourth and Fourteenth Amendments because it deprived persons of their fundamental right to life without due process of law and because there was no compelling state interest where felon did not threaten public safety). But see Gideon v. Wainwright, 372 U.S. 335, 349 (1963) (Clark, J., concurring in result) ("Constitution makes no distinction between capital and noncapital cases" because question of whether deprivation of liberty is less onerous than deprivation of life is value judgment.). Justice Clark's observation, however, was made in support of the argument that the Fourteenth Amendment cannot tolerate a procedure in criminal trials that it condemns in capital cases. This assertion does not suggest that courts should not adhere in capital cases to procedures that are observed in criminal trials, such as those emanating from the presumption of innocence.

67. In Board of Regents of State Colleges v. Roth, 408 U.S. 564, 569-70 (1972), the Court emphasized that the "range of interests protected by procedural due process is not infinite" and that prior to weighing the interests of the individual against those of the state, it must be established that the individual's interests are encompassed by the protections of the Fourteenth Amendment. Although there may be a question whether a person's life is at issue in abortion and euthanasia cases, there is no question that a capital defendant has a life interest at stake.

68. 402 U.S. 183 (1971).

69. 408 U.S. 238 (1972).

70. 428 U.S. 153 (1976).

71. Justice Black concurred in a separate opinion. See supra note 64 .

72. Death sentences imposed under the Georgia statute and the Texas statute were unconstitutional because they constituted "cruel and unusual punishment in violation of the Eighth and Four- 
filed a separate opinion in Furman. Although some of the Justices discussed the due process clause, the common ground on which the opinions necessary to support the judgment rested was the Eighth Amendment. ${ }^{73}$ As a result of Furman, capital punishment statutes in thirty-nine states and the District of Columbia were invalidated, as well as several federal statutory provisions. ${ }^{74}$ Subsequently, the Supreme Court invalidated the death sentences in 118 capital cases from twenty-six states. ${ }^{75}$

Four years later, after more than thirty states had drafted new capital punishment statutes, the Court was presented with arguments that the new sentencing procedures in five states were unconstitutional. The Justices looked at the sentencing systems to see if they resolved the concerns addressed in Furman. Because the Furman concerns derived from the Eighth Amendment, the Court's judgment that three of the systems were constitutionally adequate ${ }^{76}$ rested on the rationale that the three comported with the requirements of the Eighth Amendment. ${ }^{77}$

Although the discussion above ${ }^{78}$ illustrates that what due process analysis there is in capital sentencing carries little weight, members of the Court have continually recognized that the task they perform in capital cases is largely a procedural review. ${ }^{79}$ The Court should therefore acknowledge that adopting merely a few due process protections is inadequate in capital sentencing, where all of the key elements of due process

teenth Amendments." Furman v. Georgia, 408 U.S. at 240.

73. Chief Justice Burger criticized the approach taken in the concurring opinions of Justices White and Stewart and argued that it was "essentially and exclusively a procedural due process argument," disguised as an Eighth Amendment adjudication to avoid the McGautha precedent. Id. at 399-400 (Burger, C.J., dissenting). Justice Powell agreed with the Chief Justice's criticism, id. at 427 n.11 (Powell, J., dissenting), but also asserted that the tests for applying the due process clause and the cruel and unusual punishments clause are "fundamentally identical." Id. at 422 n.4.

74. Id. at 411-12 (Blackmun, J., dissenting).

75. McDonald, supra note 8, at 762-63.

76. See supra note 3.

77. The Court struck down the mandatory capital statutes of North Carolina and Louisiana as violative of the Eighth Amendment. Woodson v. North Carolina, 428 U.S. 280 (1976) (plurality opinion); Roberts v. Louisiana, 428 U.S. 325 (1976) (plurality opinion).

The due process clause was not discussed in depth by any of the Justices in any of the several opinions issued in the three cases upholding the Georgia, Florida, and Texas statutes. The only reference to it was in a footnote discussion of McGautha. Gregg v. Georgia, 428 U.S. at 195-96 n.47 (opinion of Stewart, Powell, \& Stevens, JJ.). Justice Rehnquist mentioned it briefly in his dissent in Woodson, 428 U.S. at 324, as did Justice White in his Roberts dissent, 428 U.S. at $348,350$.

78. See supra pp. 354-56.

79. California v. Ramos, 103 S. Ct. 3446, 3451 (1983) ("In ensuring that the death penalty is not meted out arbitrarily or capriciously, the Court's principal concern has been more with the procedure by which the State imposes the death sentence than with the substantive factors" listed in state statutes.) (emphasis in original); Barclay v. Florida, 103 S. Ct. 3418, 3429 (1983) (Stevens, J., joined by Powell, J., concurring in judgment) ("A constant theme of our cases . . . has been emphasis on procedural protections that are intended to ensure that the death penalty will be imposed in a consistent, rational manner."); Barefoot v. Estelle, 103 S. Ct. 3383, 3417 n.15 (1983) (Blackmun, J., joined by Brennan \& Marshall, JJ., dissenting) ("The Court's focus in the death penalty cases has been primarily in ensuring a fair procedure...."). 


\section{Capital Sentencing}

should apply in full force. In addition to complying with the ban on cruel and unusual punishments, ${ }^{80}$ capital sentencing statutes must reflect the fundamental due process notion that a convicted defendant is presumed to have the right to live incarcerated for the rest of his or her life ${ }^{81}$ unless the prosecution persuades the sentencing authority that death is the singularly appropriate punishment for the defendant. ${ }^{82}$

\section{Rationales for the Presumption of Life}

The rationales that support the presumption of innocence in criminal trials $^{\mathbf{8 3}}$ provide equal, if not greater, support for the presumption of life in capital sentencing proceedings. ${ }^{84}$ The presumption of life is needed to offset the advantages enjoyed by the state at capital sentencing. There, the state's cloak of authority is more manifest because the state has prevailed in the guilt-determination phase of the capital trial. The state's adversary, known throughout the trial as "the accused" or "the defendant," comes before the sentencing authority stripped of his or her presumption of innocence and labeled "the convicted." The presumption of life should ensure

80. The issue of whether the death penalty comports with the evolving standards and moral components of the Eighth Amendment is still debated, and this Note's analysis of the procedural values of the due process clause is not intended to preclude a determination that the death penalty violates the Eighth Amendment. For challenging analyses of Eighth Amendment jurisprudence and the appropriateness of capital punishment thereunder, see Berkman, Perspectives on the Death Penalty: Judicial Behavior and the Eighth Amendment, 1 YALE L. \& PoL'y REv. 41 (1982) (arguing that proper focus for Supreme Court in Eighth Amendment cases is on moral element of cruel and unusual punishments clause); Radin, The Jurisprudence of Death: Evolving Standards for the Cruel and Unusual Punishments Clause, 126 U. PA. L. REv. 989 (1978) (advocating standard of judicial review under Eighth Amendment that takes into account allocation of risk based on moral consensus).

81. Although arguments have been advanced that life imprisonment may be a harsher sanction than death, Gideon v. Wainwright, 372 U.S. 335, 349 (1963) (Clark, J., concurring in result), the magnitude and multiplicity of the current efforts by the more than 1,400 individuals on death row to have their death sentences vacated should give the proponent of such an argument pause. Only a few individuals have failed to challenge their sentences of death. See Pulley v. Harris, 104 S. Ct. 871, 889 n.5 (1984) (Brennan, J., dissenting) (Brennan was aware of four individuals who had not appealed their death sentences on their own behalf and were executed since 1976.); Greenberg, Capital Punishment as a System, 91 YALE L.J. 908, 913 (1982).

82. Much of the Eighth Amendment reasoning in Gregg and its progeny merges into the due process analysis. The observation that the "qualitative difference between death and other penalties calls for a greater degree of reliability when the death sentence is imposed," Zant v. Stephens, $103 \mathrm{~S}$. Ct. 2733, 2748 (1983) (citing Lockett v. Ohio, 438 U.S. 586, 604 (1978) (opinion of Burger, C.J.)) reinforces the distinction between the deprivation of life in capital sentencing and the deprivation of liberty in the guilt-determination phase of the trial, and strongly suggests that distinct procedural safeguards are necessary. The requirement of individualized sentencing, Zant v. Stephens, $103 \mathrm{~S}$. Ct. at 2743-44, highlights the similarity between the nature of the decision of guilt or innocence and the decision of life imprisonment or the death penalty, both of which require that the decisionmaker take into account the moral culpability of the defendant.

83. See supra pp. 359-60.

84. The capital sentencing process differs from most noncapital sentencing proceedings in its adversarial format and in the limited number of choices presented to the decisionmaker. Therefore, although the rationales may appear to apply to noncapital sentencing as well as to capital sentencing, this Note is limited to the latter. 
that neither the fact that the crime with which the defendant was charged was labeled "capital" nor the fact that the prosecution is seeking the death penalty is considered evidence in support of a sentence of death.

The presumption of life is a necessary burden-allocation device that clarifies the prosecution's obligation to produce evidence of aggravation and to persuade the jury that the death penalty is appropriate for that defendant. The capital sentencing decision, like the determination of guilt and unlike the typical noncapital sentencing decision, is binary. Just as the criminal trial jury must choose to convict or acquit, the capital sentencing authority must choose to impose either life imprisonment or the death penalty. In contrast, a noncapital sentencing authority can usually strike a balance between the conflicting interests of the parties by adjusting the length or severity of the noncapital sentence. When the evidence is balanced equally between the two sides, the binary decisionmaker therefore needs an ordering principle that dictates which party prevails. In capital cases, the prosecution comes to the court seeking to end the defendant's life; society's belief in the integrity of citizens demands that the prosecution therefore bear the burden of justifying the imposition of the death penalty on the defendant.

\section{Implications of the PResumption of Life}

The impact of the presumption of innocence on criminal trial proceedings has ranged from ensuring that defendants are not forced to appear before the jury in identifiable prison clothing ${ }^{85}$ to mandating that the prosecution prove beyond a reasonable doubt each element of the crime. ${ }^{88}$ The presumption of life makes comparable demands on capital sentencing proceedings. It provides new support for bifurcating capital trials into a penalty-determination phase and a guilt-determination phase. At a minimum, courts should instruct juries on the purging effect of the presumption of life and on the allocation of burdens during the penalty phase. In addition, states should adopt statutory provisions that will ensure that both the burdens of production and persuasion beyond a reasonable doubt are assigned to the prosecution during each phase of trial. Both trial and appellate judges reviewing jury sentences should explicitly examine the sufficiency of the evidence supporting a death sentence.

85. Estelle v. Williams, 425 U.S. 501, 503-04 (1976).

86. In re Winship, 397 U.S. 358, 363 (1970). 


\section{A. The Purging Effect of the Bifurcated Trial}

While not to be weighed as evidence in itself ${ }^{87}$ the presumption of innocence in criminal procedure, as explained above, ensures that the accused is judged solely on the evidence and arguments presented at trial. The jurors do not observe the grand jury proceeding or probable cause hearing, during which presentation of evidence not sufficiently reliable to be introduced at trial is allowed, ${ }^{88}$ and the jury is usually instructed at trial that "the defendant is presumed innocent, [and] that the mere fact of accusation is no evidence of . . guilt."

In a like manner, a capital sentencing system based on a presumption of life should prevent the determination of guilt from prejudicing the determination of the appropriate penalty by bifurcating the penalty trial from the guilt trial. ${ }^{90}$ The jury must be instructed that it cannot consider as evidence the state's decision to seek the death penalty against that particular defendant. The jury must be charged that the defendant's conviction of a capital crime creates a presumption that he or she will be sentenced to life imprisonment, and that life imprisonment is the appropriate sentence, unless, during the penalty trial, the prosecution persuades them that the only appropriate penalty for that defendant is death.

87. The Supreme Court termed the presumption of innocence to be evidence in Coffin v. United States, 156 U.S. 432, 460 (1895). After strong criticism the Court decided that the presumption was not evidence per se, Agnew v. United States, 165 U.S. 36, 51-52 (1897), but that it gave the defendant a clean slate. See A. Goldstein, supra note 56, at 1154 \& n.11.

88. Sep generally W. LAFAvE \& A. ScOTT, supra note $59, \S 4$, at 15-16 (outlining "step profile" of criminal procedure where each new point of decision requires higher degree of reliability).

89. Id. $\$ 8$, at 53 (characterizing this language as statement customarily given to jury); see Taylor v. Kentucky, 436 U.S. 478, 487-90 \& n.15 (1978) (recognizing that indictment is not to be weighed as evidence, but declining to determine whether failure to give a jury instruction to that effect violated the due process guarantee); see also A. Goldstein, supra note 56, at 1156.

90. The noncapital sentencing procedure usually occurs in a nonadversarial setting after the jury or judge has determined guilt, and the judge determines the length of sentence by relying upon ex parte reports. In most capital cases, however, the judge presides over a second trial where the penalty is determined. After a capital defendant is convicted at the guilt-determination phase of the trial, a new hearing is held in which both sides may present evidence as to the appropriate sentence and argue their positions before the sentencing authority. Under most statutes, the sentence imposed at this point is binding, although some statutes, modeled after the Florida statute, allow trial judges to reject sentences imposed by juries. See generally Gillers, Deciding Who Dies, 129 U. PA. L. Rev. 1, 102-19 (1980) (chart summarizing state capital punishment statutes). Another set of statutes, modeled after the Texas statute, provides specific questions for the jury to answer after the second phase. The responses to the questions determine whether the death sentence will be imposed. For a comprehensive analysis of the Texas statute, see Black, Due Process for Death: Jurek v. Texas and Companion Cases, 26 Cath. U.L. Rev. 1, 3-10 (1976), reprinted in G. BLAcK, supra note 64, at 114-25. See generally A. LEFF, Leff's Legal Dictionary, 94 Y ALE L.J. (forthcoming) (1985) (bifurcated trial defined as "split trial or other hearing" that "can save litigation effort" and "prevent the transfer of irrelevant and prejudicial information between segments of the same case"); Comment, The Bifurcated Trial: Is It Used More Than It is Useful?, 31 EMORY L.J. 441, 441 (1982) (proponents of bifurcation in determination of defendant's sanity in noncapital trials assert that: (1) it prevents determination of one issue from prejudicing another; (2) it simplifies necessary decisions; (3) it allows defendant to put forth inconsistent positions in different proceedings). 
Bifurcation is perhaps the most distinctive feature of the capital punishment statutes upheld by the Supreme Court in $1976 .{ }^{.1}$ It is a feature that all states with capital punishment statutes have subsequently adopted. ${ }^{92}$ Although the bifurcated capital trial was not altogether new in 1976, ${ }^{93}$ the Court stated in Gregg v. Georgia that it was one of the features of the Georgia system that helped guide and channel the jury's discretion. ${ }^{94}$ The Court noted that the bifurcated trial also protects the integrity of the guilt-determination phase; bifurcation allows the jury to decide the issue of guilt before hearing evidence prejudicial to deciding that issue but helpful in choosing a sentence. ${ }^{95}$ The benefits of bifurcated trials stressed by the Court in Gregg thus correspond to the requirement in the presumption of life analysis that the decision of guilt not prejudice the choice of sentence.

In light of recent decisions, it is uncertain whether the Court would now consider a bifurcated proceeding a constitutionally essential aspect ${ }^{28}$ of the sentencing systems upheld in 1976. The Court has also never expressly overruled its 1971 holding in Crampton v. Ohio, ${ }^{97}$ where it re-

91. The Court specifically noted the bifurcation feature in each of the three sentencing schemes it upheld. Gregg v. Georgia, 428 U.S. 153, 163 (1976) (opinion of Stewart, Powell, \& Stevens, JJ.); Proffitt v. Florida, 428 U.S. 242, 246 (1976) (opinion of Stewart, Powell, \& Stevens, JJ.); Jurek v. Texas, 428 U.S. 262, 267 (1976) (opinion of Stewart, Powell, \& Stevens, JJ.). Justices Stewart, Powell, and Stevens, in the central Gregg opinion commented that "[a]s a general proposition these concerns [in Furman] are best met by a system that provides for a bifurcated proceeding at which the sentencing authority is apprised of the information relevant to the imposition of sentence and provided with standards to guide its use of the information." 428 U.S. at 195. Although these Justices expressly stated that the procedures they described were not the only permissible ones, Justice White read the opinion in Roberts $v$. Louisiana, written by the same three Justices, as holding that a bifurcated proceeding is constitutionally required in capital cases. Roberts v. Louisiana, 428 U.S. 325,356 (1976) (White, $J$, dissenting). The Court continues to rely on the central opinion's general proposition. Pulley v. Harris, 104 S. Ct. 871, 876-77 (1984).

92. See Gillers, supra note 90 , at 102-19.

93. California, Connecticut, Georgia, New York, Pennsylvania, and Texas had bifurcated capital trials at the time of Crampton v. Ohio, 402 U.S. 183, 208 \& n.19 (1971) (decided with McGauthav. California). For an early analysis of the use of the bifurcated trial in capital cases, see Note, The Two-Trial System in Capital Cases, 39 N.Y.U. L. REv. 50 (1964).

94. Gregg v. Georgia, 428 U.S. 153, 195 n.46 (1976) (opinion of Stewart, Powell, \& Stevens, JJ.).

95. Id. at 191-92.

96. The reasoning of the majority of the Supreme Court in Harris may indicate that no one particular procedure in the three sentencing systems upheld in 1976 is constitutionally essential. See Pulley v. Harris, 104 S. Ct. 871, 881 (1984), and discussion supra note 4. This interpretation of the Eighth Amendment cases reinforces the need to look to the due process clause as the only meaningful foundation for procedural safeguards in capital sentencing. Commentators have stopped short of directly arguing that bifurcation is constitutionally required. See, e.g., Weisberg, supra note 28, at 309 (Crampton has "essentially been overruled," and state officials view Supreme Court as "virtually requiring" bifurcation) (footnote omitted); The Supreme Court, 1977 Term, 92 Harv. L. Rev. 57, 103 n.38 (1978) (suggesting that Lockett v. Ohio, 438 U.S. 586 (1978), may establish constitutional right to bifurcated proceeding).

97. 402 U.S. 183, 208-22 (1971) (decided with McGautha v. Califormia) (rejecting defendant's angument that unitary proceeding in capital case was unconstitutional because it forced defendant to forgo either constitutional right to refuse to testify or constitutional right to have sentence imposed 
jected the argument that bifurcation is constitutionally compelled to ensure that the defendant is not forced to choose between competing constitutional rights. ${ }^{98}$ In a system based on the presumption of life, however, the bifurcated trial is crucial to give that presumption practical effect.

\section{B. Allocation of Burdens to the Prosecution}

In criminal trials, the presumption of innocence allows the accused to "'remain inactive and secure, until the prosecution has taken up its burden and produced evidence and effected persuasion." "'99 The presumption requires that the prosecution convince the jury not merely that the evidence of guilt exists and that it preponderates, but that the defendant is guilty beyond a reasonable doubt. ${ }^{100}$ Similarly, the presumption of life should allow a defendant to remain inactive during the penalty phase until the prosecution has produced evidence sufficient to reasonably support a finding that a sentence of death is appropriate beyond a reasonable doubt. Under most current capital sentencing systems, the prosecution meets the burden of production of aggravating evidence to support a death sentence during the guilt phase because the sentencing authority is permitted to consider all evidence presented during both phases of the trial in its choice of sentence. ${ }^{101}$ In its most recent examination of the Georgia sys-

only after opportunity to address sentencing authority and have all relevant evidence presented). Apparently, two years earlier, the Court had voted six to three to declare that a bifurcated trial was required. B. Woodward \& S. ARmSTrong, The Brethren 205-06 (1979). No opinion was ever published, however, and the case was remanded on other grounds. Maxwell v. Bishop, 398 U.S. 262 (1970) (per curiam). In McGautha, the Court also rejected the defendants' arguments that imposition of the death penalty by a jury with absolute discretion was unconstitutional. 402 U.S. at 196-208.

98. The Court has acknowledged that in light of Furman v. Georgia, 408 U.S. 238 (1972), McGautha, decided with Crampton, must be read narrowly. Gregg v. Georgia, 428 U.S. 153, 196 n.47 (1976) (opinion of Stewart, Powell, \& Stevens, JJ.). But see Furman v. Georgia, 408 U.S. at 400 (Burger, C.J., dissenting) ("[I]t would be disingenuous to suggest that today's ruling has done anything less than overrule McGautha in the guise of an Eighth Amendment adjudication."); id. at 427 n.11 (Powell, J., dissenting) ("McGautha simply cannot be distinguished.").

Whether references to the limited scope of McGautha's authority were meant also to refer to Cramplon is difficult to discern because of the combined decision in 1971. The footnote in Gregg narrowing the precedential value of McGautha referred to McGautha as holding that the due process clause did not require a bifurcated trial. There was no reference to Crampton, nor was there any subsequent discussion of Furman's effect on whether bifurcation is constitutionally required. None of the numerous opinions in the three 1976 cases upholding the bifurcated trial systems in Georgia, Florida, and Texas even cited Crampton. Crampton's death sentence was vacated in 1972 in light of the holding in Furman. Crampton v. Ohio, 408 U.S. 941 (1972). McGautha's death sentence was vacated by the California Supreme Court in light of an intervening case that declared that the current state death penalty statute violated the California Constitution. People v. Anderson, 6 Cal. 3d 628, 493 P.2d 880, 100 Cal. Rptr. 152 (en banc), cert. denied, 406 U.S. 958 (1972).

99. Taylor v. Kentucky, 436 U.S. 478, 484 n.12 (1978) (quoting 9 J. Wigmore, A Treatise oN THE ANGlo-American SySTEM OF Evidence 407 (3d ed. 1940)).

100. In re Winship, 397 U.S. 358, 363 (1970).

101. The presumption of life may require that a new jury be impaneled for the sentencing phase and/or that the prosecution be required to reintroduce all evidence of aggravating circumstances during the sentencing phase. This Note does not, however, reach these issues, but is intended as only the first step in the examination of the implications of the presumption of life. Further examination of 
tem, the Supreme Court reinforced this lenient attitude regarding the admission of aggravating evidence. ${ }^{102}$ Nevertheless, nearly all state statutes place on the prosecution the burden of proving the existence of any statutory circumstances that it submits to the sentencing authority. ${ }^{103}$

Many states have neglected to assign the second and more fundamental burden, that of persuading the sentencing authority that the defendant is legally deserving of the death penalty. ${ }^{104} \mathrm{~A}$ few states, however, have in-

issues such as these should be undertaken by legislatures and courts in the future in an effort to give full meaning to the presumption of life.

102. The Court has apparently adopted the position that proof of one statutory aggravating circumstance adequately narrows the class of capital defendants to those who are eligible for the death penalty. Zant v. Stephens, 103 S. Ct. 2733, 2741-42 (1983). The Court also approved the trial court's consideration of aggravating factors not enumerated in the statute, as long as the underlying evidence is admissible. Id. at $2747-48$.

103. See generally Gillers, supra note 90 , at 102-19 (indicating which state capital punishment statutes place burden on state of proving existence of aggravating circumstances). The North Carolina Supreme Court has described the burden: "Where it is doubtful whether a particular aggravating circumstance should be submitted, the doubt should be resolved in favor of defendant." State v. Oliver, 302 N.C. $28,61,274$ S.E.2d 183, 204 (1981).

The majority of states require that the prosecution prove beyond a reasonable doubt the existence of at least one of the aggravating factors listed in the statute. Evidence of further statutory aggravating circumstances is presented by the state, usually bound by the rules of evidence concerning relevance. The aggravating factors included in the Georgia statute that was upheld in Gregg are typical of those in most statutes. The factors include: the murder being committed at the same time as another lifeendangering crime, a murder committed for the purpose of receiving money, a murder of a judicial officer or of a peace officer, a murder committed in an especially vile manner, and a murder committed for the purpose of avoiding arrest. See Gregg v. Georgia, 428 U.S. 153, 165 n.9 (1976) (opinion of Stewart, Powell, \& Stevens, JJ.).

The defendant can present any factors in mitigation and generally is not bound by the rules of evidence. Lockett v. Ohio, 438 U.S. 586, 604-08 (1978) (opinion of Burger, C.J.). Mitigating factors can be "any aspect of a defendant's character or record and any of the circumstances of the offense that the defendant proffers as a basis for a sentence less than death." Id. at 604 (footnote omitted).

104. The determination of guilt in a criminal trial has been characterized as a factual finding by the jury that is distinguishable from the "normative, policy decision" involved in the capital sentencing determination. This distinction has been used to argue that a burden of "proof" is therefore applicable in the first instance, but not in the latter. Ford v. Strickland, 696 F.2d 804, 831 n.17 (11th Cir.) (Tjoflat, J., concurring in part and dissenting in part) \& $845 \mathrm{n} .2$ (Kravitch, J., concurring in part and dissenting in part), cert. denied, 104 S. Ct. 201 (1983). But see id. 696 F.2d at 877-83 (Anderson, J., concurring in part and dissenting in part) (asserting that courts can and should apply concept of burden of proof to the weighing process in capital sentencing decisions because its practical function is to set forth degree of confidence decisionmaker should have in his or her conclusion). In Bullington v. Missouri, 451 U.S. 430, 450 (1981) (Powell, J., joined by Burger, C.J., White \& Rehnquist, JJ., dissenting), Justice Powell asserted that an "objective truth" underlies the question of guilt or innocence, whereas sentencing is the meting out of just deserts, and therefore any question of whether procedures in capital sentencing are similar to trial procedures is inappropriate. This reasoning ignores the fact that the trial jury makes judgments on nonfactual issues as well as the distinctions between capital and noncapital sentencing. In Zant v. Stephens, 103 S. Ct. 2733, 2755 (1983) (Rehnquist, J., concurring in judgment), Justice Rehnquist atiempted to distinguish the jury's determination of guilt from its decision to impose death by the fact that the sentencing jury does not decide "whether particular elements have been proved." Most state statutes, including Georgia's, do however, place a burden of proof of aggravating circumstances on the prosecution, see supra notes 102 and 103, and some states give instructions on weighing them.

The determination of guilt is not, however, an issue of pure fact, but rather one requiring the decisionmaker to make a finding of moral culpability, see supra note 61. Likewise, the capital sentencing authority first determines the purely factual issues of the existence of aggravating and/or mitigating circumstances, and then makes a finding of whether the defendant is morally deserving of the 
cluded a provision in their capital punishment statutes assigning a burden of persuasion to the prosecution, ${ }^{105}$ and some state courts have adopted such a requirement. ${ }^{108}$ The Supreme Court has implicitly acknowledged the appropriateness of using standardized jury instructions to assign a burden of persuasion in death sentencing to the prosecution. ${ }^{107}$

The practical import of the allocation of burdens of production and persuasion is that the judge must instruct the jury not only as to who bears the burdens, but also as to what the burdens mean and how they can be met. Courts and legislatures that have attempted to define the burdens have been fairly consistent in discerning three specific issues. A useful example is the Arkansas state statute that provides in part:

(1) The jury shall impose a sentence of death if it unanimously returns written findings that:

(a) aggravating circumstances exist beyond a reasonable doubt; and

(b) aggravating circumstances outweight [outweigh] beyond a reasonable doubt all mitigating circumstances found to exist; and

(c) aggravating circumstances justify a sentence of death beyond a reasonable doubt. ${ }^{108}$

death penalty. In both the decisions on guilt and on death, the prosecution cannot prove its charge but can only prove the underlying facts and then convince the decisionmaker of the moral appropriateness of the decision. In Utah, one of the states that does place a burden of persuasion on the prosecution during the sentencing phase of capital trials, the state supreme court has emphasized that:

[the] standard has to do with the degree of persuasion or certitude on the part of the sentencing

authority about the decision to sentence to death. It does not affect or change standards relating

to the burden of proof of facts borne by the prosecution at either the guilt or the penalty phase of the trial.

Andrews v. Morris, 677 P.2d 81, 84 (Utah 1983).

105. See, e.g., Ark. Stat. ANn. \$ 41-1302 (1)(c) (1977).

106. See, e.g., State v. Wood, 648 P.2d 71, 83 (Utah), cert. denied, 459 U.S. 988 (1982) (Utah Supreme Court concluded that sentencing authority must be "persuaded beyond a reasonable doubt that total aggravation outweighs total mitigation, and [they] must further be persuaded, beyond a reasonable doubt, that the imposition of the death penalty is justified and appropriate in the circumstances." ") (emphasis added).

107. In its interpretation of the Missouri statute and the Missouri Approved Criminal Instructions, the United States Supreme Court acknowledged that it is appropriate to compel "the jury to determine whether the prosecution has "proved its case" in a capital sentencing proceeding. Bullington v. Missouri, 451 U.S. 430, 444 (1981); see also Arizona v. Rumsey, 104 S. Ct. 2305 (1984). One member of the Supreme Court has specifically acknowledged that a capital sentencing authority must be persuaded of more than the following facts: (1) that an aggravating factor exists, (2) that the aggravating circumstances are sufficiently substantial to call for the death penalty, and (3) that the aggravating circumstances outweigh the mitigating circumstances. Justice Stevens observed that "a jury might answer [these] questions affirmatively and yet feel that a comparison of the totality of the aggravating factors with the totality of mitigating factors leaves it in doubt as to the proper penalty. But the death penalty can be constitutionally imposed only if the procedure assures reliability in the determination that "death is the appropriate punishment in a specific case." 'Smith v. North Carolina, 459 U.S. 1056, 1056-57 (1982) (Stevens, J., opinion respecting denial of certiorari) (quoting in part Lockett v. Ohio, 438 U.S. 586, 601 (1978) (opinion of Burger, C.J.)); see also Ford v. Strickland, 696 F.2d 804, 879 n.7 (11th Cir.) (Anderson, J., concurring in part and dissenting in part) (describing both statutory provisions and case law in various states concerning burdens applied in their capital sentencing systems), cert. denied, 104 S. Ct. 201 (1983).

108. ARK. Stat. ANN. $\S 41-1302$ (1977) (bracketed word inserted by compiler of official code). 
A constitutionally precise statute would also, at a minimum, limit the jury's consideration to aggravating circumstances listed in the statute and require the jury to be persuaded that the death penalty was appropriate, in the circumstances of the particular case, beyond a reasonable doubt. ${ }^{109}$

The weight of the burden of persuasion assigned to the state can make an important difference in many criminal cases. ${ }^{110}$ We need not and should not, however, derive the standard of persuasion for capital sentencing from the Eighth Amendment. ${ }^{111}$ Instead, a capital sentencing system that accepts the presumption of life as a core component of due process can draw support for requiring the prosecution to bear the burden of persuasion beyond a reasonable doubt from the analogous due process implications of the presumption of innocence in criminal trials. ${ }^{112}$

The suggestions set forth here are intended not to be exhaustive but only illustrative of the due process safeguards arising out of the presumption of life.

109. See Smith v. North Carolina, 459 U.S. 1056 (1982) (Stevens, J., opinion respecting denial of certiorari). Justice Stevens recognized the importance of such a requirement in his reference to the Wood standard, supra note 106, which contains such a provision, to cure a defect in North Carolina jury instructions similar to the problem in the Arkansas statute. Justice Marshall has relied on this standard to argue that both the Maryland capital sentencing system, Stebbing v. Maryland, $105 \mathrm{~S}$. Ct. 276, 279-80 (1984) (Marshall, J., dissenting from denial of certiorari), and the Pennsylvania system, Maxwell v. Pennsylvania, 105 S. Ct. 370, 371-72 (1984) (Marshall, J., joined by Brennan, J., dissenting from denial of certiorari), are constitutionally infirm.

110. In the seminal case of In re Winship, 397 U.S. 358, 367 (1970), which held that proof beyond a reasonable doubt was the constitutionally required standard of persuasion in criminal trials, the Supreme Court rejected the assertion that there was only a tenuous difference between standards. The Court noted that the trial judge below had applied a preponderance of the evidence standard and made a "finding of guilt that he conceded he might not have made under the standard of proof beyond a reasonable doubt." The significance of the choice of standard was highlighted in State v. Wood, 648 P.2d 71 (Utah), cert. denied, 459 U.S. 988 (1982), where the defendant was sentenced to death under the preponderance standard, but, according to the trial judge, would not have been sentenced to death under the reasonable-doubt standard. The Supreme Court of Utah, in vacating the sentence of death based on a mere preponderance of the evidence, rejected "the proposition that the death penalty may be imposed when there is substantial doubt whether it should be." Id. at 80 .

111. Arguments that "'proof beyond a reasonable doubt' should be the required standard of proof at all stages of the death penalty proceeding" because the values of the Eighth Amendment require it, may be compelling, but are constitutionally misplaced. See Note, supra note 35, at 338-42 (advocating that reasonable-doubt standard of proof be required under Eighth Amendment at all stages of death penalty proceeding). Such arguments simply perpetuate the selective application of specific due process guarantees through the Eighth Amendment.

112. The argument that the Constitution requires that the appropriateness of the death penalty be established beyond a reasonable doubt has been rejected by the Ninth Circuit, Harris v. Pulley, 692 F.2d 1189, 1194-95 (9th Cir. 1982) (rejecting argument because court was "not aware of any instance where the state must carry such a burden of proof when attempting to convince a sentencing authority," and because if Supreme Court intended it, "it would have said so"), but the argument has not been addressed by the United States Supreme Court. See Pulley v. Harris, 104 S. Ct. 871,874 n.4 (1984) (grant of certiorari did not extend to this issue); see also Andrews v. Morris, 677 P.2d 81, 85 n.2 (Utah 1983) (reasonable-doubt standard of persuasion required under statutory construction but not necessarily constitutionally compelled); Amsterdam, Anthony Amsterdam Analyzes New Mexico Death Penalty Statute, 1 Death Penalty ReP. 1, 2 (1980) (judgment of death sentence is "precise analogue" to conviction of guilt and therefore due process requires proof beyond reasonable doubt); Weisberg, supra note 28, at 342 n.160 (suggesting that arguments for reasonable-doubt standard may be made under either Fifth or Eighth Amendment). 


\section{Capital Sentencing}

The due process rationale that the Court used in In Re Winship, ${ }^{113}$ to establish the requirement of the reasonable-doubt standard in criminal trials, is equally valid for capital sentencing. The Supreme Court stated in Winship that "[i]t is critical that the moral force of the criminal law not be diluted by a standard of proof that leaves people in doubt."114 The Court reasoned that " $[t]$ he standard provides concrete substance for the presumption of innocence," "115 and that "the reasonable-doubt standard is indispensable, for it impresses on the trier of fact the necessity of reaching a subjective state of certitude . . ." "'116 Justice Harlan, reasoning that society views the conviction of an innocent person as far worse than the acquittal of a guilty person, concurred that the reasonable-doubt standard was required. ${ }^{117}$

A reasonable-doubt standard for capital sentencing would impress upon the sentencer the degree of certitude necessary to impose the death penalty on an individual. Given the Supreme Court's practice of imposing higher standards of proof where the chance of error is high, ${ }^{118}$ a system fraught with as much possibility for error as capital sentencing ${ }^{119}$ demands, at a minimum, a standard offering the highest degree of certitude. ${ }^{120}$ The irrevocability and finality of the decision also compel such a standard in light of the Court's practice of requiring a higher degree of certainty with increasingly important interests. ${ }^{121}$ The execution of an undeserving individual would be far worse than imprisoning for life one for whom death could be judged appropriate. ${ }^{122}$ Therefore, the reasonable-doubt standard of persuasion should be placed on the prosecution in capital sentencing proceedings.

113. 397 U.S. 358 (1970).

114. Id. at 364 .

115. Id. at 363.

116. Id. at 364 (quoting Dorsen \& Rezneck, In Re Gault and the Future of Juvenile Law, 1 FAM. L.Q. 1, 26 (1967)).

117. Id. at 372 (Harlan, J., concurring).

118. Santosky v. Kramer, 455 U.S. 745, 762-66 (1982) (magnified risk of erroneous factfinding at parental rights termination proceeding); Addington v. Texas, 441 U.S. 418, 427 (1979) (risk of reliance on isolated instances of unusual conduct in civil commitment proceeding).

119. See C. BLACK, supra note 64 .

120. Ford v. Strickland, 696 F.2d 804, 879-81 (11th Cir.) (Anderson, J., concurring in part and dissenting in part) (arguing that court of appeals should follow reasoning of Addington and impose reasonable-doubt standard in death penalty cases), cert. denied, 104 S. Ct. 201 (1983).

121. See Mullaney v. Wilbur, 421 U.S. 684, 697-98 (1975) (holding that Winship applied in determining the severity of sentence because potential difference in restrictions of personal liberty is of great importance). The Court points out that applying the same standard of persuasion throughout the proceeding prevents the state from evading the effect by redefining the crimes. Id. at 698 .

122. This value has long been part of the common law tradition. $4 \mathrm{~W}$. BLAckstone, supra note 8, *358 ("[T]he law holds that it is better that ten guilty persons escape, than that one innocent suffer."). If the Court continues to believe that it is better that a guilty person go free than that an innocent person suffer, how can it not agree that it is better that one who deserves death should live, than that one who deserves life should die? 


\section{New Procedural Mechanisms}

New procedural mechanisms must be introduced in capital sentencing proceedings analogous to those imposed on the prosecution in criminal trials, to force the state to meet its burdens of production and persuasion. ${ }^{123}$ First, before presenting any evidence of mitigating circumstances at the penalty phase, or if no mitigating evidence is going to be presented, prior to arguments to the jury, the defendant should be able to submit a motion for a directed sentence of life on the basis that the prosecution has submitted insufficient evidence of the existence of statutory aggravating circumstances to establish beyond a reasonable doubt that the defendant is deserving of the death penalty. ${ }^{124}$ The court should determine whether any rational sentencing authority could have determined the existence of the minimal requirements of the sentence beyond a reasonable doubt. ${ }^{125}$ If the motion is granted, and a verdict of life imprisonment is entered, the verdict should be final. The double jeopardy concerns that preclude appeal or retrial of an acquittal ${ }^{126}$ are equally valid here. Second, if the court denies the motion for a directed sentence, the defendant should be able to present evidence in mitigation and/or present a final argument to the jury. If, after arguments by both parties, a verdict of death is issued, the defendant should be able to submit a motion for a life sentence notwithstanding the sentence of death, arguing that the sentence should be set aside as contrary to the evidence. ${ }^{127}$

The automatic appellate review to state supreme courts that currently is required in all capital punishment statutes ${ }^{\mathbf{1 2 8}}$ should be extended from the

123. See generally W. LAFAve \& A. ScoTT, supra note 59, § 8, at 53-56 (discussing mechanisms in traditional criminal trials by which defense can force prosecution to put forth evidence and discussing role of judge in this process).

124. Cf. id. $\S 8$, at 44 (judge must grant motion for directed verdict of acquittal "if evidence is such that reasonable [jurors] must necessarily have a reasonable doubt"); see also Jackson v. Virginia, 443 U.S. 307,318 (1979) (critical inquiry on review of sufficiency of evidence to support criminal conviction is "to determine whether the record evidence could reasonably support a finding of guilt beyond a reasonable doubt").

125. Cf. Jackson v. Virginia, 443 U.S. 307, 319 (1979). See supra pp. 369-70 for discussion of proposed minimal requirements.

126. Burks v. United States, 437 U.S. 1, 16 (1978) (where trial judge or appellate court finds evidence insufficient to sustain guilt, judgment of acquittal entered and retrial for same offense prohibited); see also Bullington v. Missouri, 451 U.S. 430,445 (1981) (double jeopardy prohibited prosecution from seeking death penalty at retrial, where they had sought and failed to get it at first trial and defendant was implicitly acquitted of death penalty); Arizona v. Rumsey, 104 S. Ct. 2305, 2310 (1984) (same); $f f$. Kamisar, Lafave \& Israel, Modern Criminal Procedure: Cases, ComMENTS AND QUESTIONS 456 n.a (1984 Supp. to 5th ed.) (distinguishing Bullington v. Missouri from United States v. DiFrancesco, 449 U.S. 117 (1980), where government was allowed to seek harsher sentence on appeal in noncapital case).

127. Cf. W. LAFAve \& A. ScotT, supra note $59, \S 8$, at 55 (judge applies sufficiency of evidence test in ruling on motion for judgment of acquittal notwithstanding verdict after close of case).

128. Pulley v. Harris, 104 S. Ct. 871, 876 (1984). 


\section{Capital Sentencing}

limited review described in Gregg $^{129}$ to a review of whether the evidence supports the determination of the existence of the minimal requirements of the sentence beyond a reasonable doubt. A finding of evidence insufficient to support the sentence by the appellate court would operate as an acquittal, imposing a life sentence and barring resentencing. ${ }^{130}$ Introducing this traditional judicial review of the sufficiency of the evidence for death sentences in capital cases, as well as for convictions, will make appellate review more meaningful. ${ }^{131}$

\section{ConClusion}

The due process clause of the Fourteenth Amendment protects an individual's interest in life as well as in liberty and property. Just as we presume that a defendant in a criminal trial is innocent, so must we presume that a defendant in a capital sentencing proceeding deserves a life sentence. The Supreme Court should abandon its Eighth Amendment procedural analysis of capital sentencing, recognize a presumption of life based on the values of the due process clause as the constitutional starting point, and determine what, if any, procedural safeguards are adequate to ensure that the extraordinary sanction of death is not imposed in an unconstitutional manner.

-Beth S. Brinkmann

129. Appellate review under the statute in Gregg, which most state statutes followed, provides for a three-part review to determine if: (1) the sentence was imposed under influence of passion or prejudice; (2) the evidence supports the finding of an aggravating circumstance; and (3) the sentence is disproportionate to sentences in similar cases in the state. Gregg v. Georgia, 428 U.S. 153, 212 (1976) (White, J., concurring in judgment). But see Pulley v. Harris, 104 S. Ct. 871, 879 (1984) (proportionality review not necessarily an element of meaningful appellate review upon which Gregg was based).

130. Cf. Burks v. United States, 437 U.S. 1, 10, 16 (1978).

131. See Dix, Appellate Review of the Decision to Impose Death, 68 GEo. L.J. 97 (1979) (examining major flaws of current appellate review and detailing failure of Georgia, Florida, and Texas appellate review processes to achieve uniformity or objective standards). 